Bedru Babulo Balana, Muys, B., Nigussie Haregeweyn, Descheemaeker, K., Deckers, J., Poesen, J., Nyssen, J., Mathijs, E., 2012. Cost-benefit analysis of soil and water conservation measures: The case of exclosures in northern Ethiopia. Forest Policy and Economics, 15: 27-36.

\title{
Cost-benefit analysis of soil and water conservation measure: The case of exclosures in northern Ethiopia
} \author{
Jean Poesen ${ }^{\mathrm{b}}$, Jan Nyssen ${ }^{\mathrm{f}}$, Erik Mathijs ${ }^{\mathrm{b}}$ \\ a The James Hutton Institute, Social, Economic \& Geographical Sciences Group, Craigiebuckler, Aberdeen AB15 8QH, Scotland, UK \\ ${ }^{\mathrm{b}}$ Katholieke Universiteit Leuven, Department of Earth and Environmental Sciences, Celestijnenlaan 300, B-3001 Leuven, Belgium \\ ' Arid Land Research Center, Tottori University, 1390 Hamasaka, Tottori 680-0001, Japan \\ d CSIRO Ecosystem Sciences, PMB 2, Glen Osmond, SA 5064, Australia \\ e Department of Land Resources Management and Environmental Protection, Mekelle University, P.O. Box 231, Ethiopia \\ ${ }^{\mathrm{f}}$ Ghent University, Department of Geography, Krijgslaan 281(S8), B-9000 Gent, Belgium
}

Bedru Babulo Balana ${ }^{\mathrm{a}, *}$, Bart Muys ${ }^{\mathrm{b}}$, Nigussie Haregeweyn ${ }^{\mathrm{c}, \mathrm{e}}$, Katrien Descheemaeker ${ }^{\mathrm{d}}$, Jozef Deckers ${ }^{\mathrm{b}}$,

\section{Abstract}

This paper is about the cost-benefit analysis of a specific soil and water conservation measure, commonly termed as 'exclosures' in the case study area of this research, adopted in the Tigray region of northern Ethiopia. The analysis integrated available data on on-site and off-site effects of the conservation measure. Major benefit and cost items related to this specific measure were identified, quantified, and valued. Direct market prices and variants of indirect environmental valuation techniques (cost based and productivity change methods) were employed in valuing the benefit and cost items included in the analysis. Our results indicate that establishing exclosures in degrading marginal lands generate a large positive net present value (NPV) of ETB $5620 \mathrm{ha}^{-1}$. However, putting productive agricultural land under exclosures yields a negative NPV even under some hypothetical scenarios of $50 \%$ rise in prices of forest products and a social discount rate halved from the base rate of $8 \%$. Sensitivity analyses indicate that the net present value is quite volatile to changes in biomass production and the social discount rate.Thus, appropriate forest management schemes have to be adopted in order to maximize sustainable biomass production. Furthermore, factors such as credit constraints that affect local people's time preference should be addressed to induce local people to discount the future at lower rate.

\section{Introduction}

Land degradation and moisture stress are the major environmental threats in Tigray region of northern Ethiopia. This problem is largely attributable to the rapid dwindling of forest resources in the region (Teketay, 2001; Tadesse, 2001). In the beginning of the 19th century, about $40 \%$ of Ethiopia's land mass was said to be covered by natural forests (Campbell, 1991; Gillam, 2004; Tilahun et al., 2007). The scene has continuously been changing in the twentieth century and today the nation's forested areas have shrunk to less than $3 \%$ of the total land area. The situation is much more severe in Tigray than in many other parts of Ethiopia. According to the 1996 report of the Tigray Forestry Action Plan, forests and woodlots cover less than $2 \%$ of the region's total area (TFAP, 1996). This massive loss of vegetation cover complemented with the region's mountainous and hilly topography and torrential rainfall aggravated the scale and extent of water erosion in the region (Bojo and Cassels, 1995; Bojo, 1996; Esser et al., 2002).

To mitigate the problem several soil and water conservation measures were undertaken in the study region. Protecting degraded areas from human and animal interventions to stimulate natural regeneration of plants (commonly termed as exclosures ${ }^{1}$ ) is one of the widely practiced conservation measures in the region. Exclosures basically entail a change in land use and are being implemented by setting aside land, mainly grazing lands or community woodlands, and preventing human and livestock interference to promote natural vegetation. The protection is regulated by local bylaws and ensured through community appointed local guards. Besides the ecological services, exclosures are also expected to boost biomass production, mainly fuel wood and fodder, to satisfy the growing demand for these products. If harvested in a sustainable manner, biomass production can substitute the use of animal dung and crop residues for fuel without impairing the environmental functions of forests so that dung and crop residues could 
be applied in farm field to improve soil fertility and agricultural yields (Anderson, 1987).

As part of the water resource development scheme, harvesting seasonal runoff via earth dams and small ponds (locally termed as 'horoye') is also widely practiced in Tigray. However, sedimentation threatens the sustainability of the reservoirs (Haregeweyn et al., 2006). By trapping the incoming sediments exclosures effectively act as buffer strips in reducing sediment inflow into the reservoirs. The sediment trapping capacity of exclosures also minimizes the negative effects of flooding damage on adjacent cropland in down-slope locations (Descheemaeker et al., 2006).

However, establishing exclosures excludes land from competing uses which obviously entails an opportunity cost. Thus, to ensure efficiency in land reallocation the present and future flows of benefits and costs need to be identified, valued, and evaluated. However, such quantitative economic analyses of exclosure establishment have not yet been undertaken in Tigray region. By pooling available data on biomass production, soil erosion, soil hydrology, sedimentation, crop yields, and opportunity cost of land; the principal objective of this paper was to assess the costs and benefits of establishing exclosures in highland areas of the Tigray region.

The paper is organized as follows. The next section briefly reviews the theoretical basis of cost-benefit analysis (CBA) in environmental analysis. Section 3 describes the on-site and off-site effects of vegetation restoration in exclosures. Section 4 gives detailed discussion of the techniques pursued to quantify and value the various benefit and cost items and the framework of analysis. Sections 5 and 6 present the results of the analysis. The last two sections present discussions and concluding remarks.

\section{Theoretical basis of CBA in environmental analysis}

Mainstream economics postulates that economic trade-offs inevitably arise when a scarce resource is allocated to a specific use. Private agents, motivated by self interest, seek some guiding economic tools to allocate their resources optimally in order to achieve their objectives. The problem becomes more serious and complicated in public resource allocation. This is because public economic decisions involve a series of externalities and trade-offs that necessitate careful accounting of the social impacts of the decision. Cost-benefit analysis (CBA) is an applied economic tool often used to guide economic agents in resource allocation or investment project decisions or policy alternatives. It is a technique that is used to estimate and sum up (in present terms) the future flows of benefits and costs of society's resource allocation decisions or policy alternatives to establish the worthiness of undertaking the stipulated activity or alternative and inform the economic efficiency to the decision maker. In many instances CBA is applied in natural resource conservation policies (Anderson, 1987; Newcombe, 1987; Grohs, 1993; Jagger and Pender, 2003; Tilahun et al., 2007).

The basic rationale for CBA is rooted in the principle of potential compensation developed by Kaldor and Hicks (Hicks, 1939; Kaldor, 1939), commonly known as the Kaldor-Hicks criterion. It states that an action is more efficient if those that are made better off could potentially compensate those that are made worse off and lead to a Pareto optimal outcome. ${ }^{2}$ In situations where benefits and costs of an action spread over time, decisions are based on by comparing of the present value of benefits and costs.

With regard to decisions related to environmental conservation, a particular conservation decision results in, for instance, differences in the stock and flow of the natural resource system under consideration. The role of $\mathrm{CBA}$ is to measure the benefits and costs of the differences

\footnotetext{
${ }^{2}$ Unlike the Pareto criterion, the Kaldor-Hicks criterion does not require actual payment of the compensation, i.e., it is sufficient for the Kaldor-Kicks criterion if the possibility for compensation exists and that it is potentially conceivable.
}

and consequently $\mathrm{CBA}$ enables the comparison of the two worlds: the world with the conservation measure and the world without it. However, applying CBA in environmental conservation involves variety of challenges. One major challenge arises from the fact that many environmental goods and services are not traded directly in the market. Hence, attaching economic values to them becomes a difficult task. In spite of remarkable developments in non-market valuation methods the challenge of attaching accurate and true economic values to a large number of environmental goods and services still remains unresolved. Another major controversy in applying CBA to environmental conservation is the choice of the discount rate for discounting the future flows of benefits and costs. From an economic point of view the discount rate should reflect the social time preference. As ecosystem functions are complex and some environmental changes are irreversible, the choice of the discount rate is not as simple as for private business investment decisions. Choosing a relevant time horizon from the perspective of local people is another important consideration in CBA application. Despite the challenges, CBA remains an important analytical tool in environmental decision.

\section{On-site and off-site effects of exclosures}

Exclosures provide essential functions in terms of trapping incoming sediments and increasing water infiltration. They accelerate fertile soil build-up and prevent important sediment loads leaving the catchment or silting downstream water reservoirs. Descheemaeker et al. (2006) assert that under the influence of vegetation and sediment deposition dark soils rich in organic matter develop on-site in exclosures of the Tigray highlands. Generally, one may examine the soil and water conservation effects of exclosures in three locations where they actually or potentially occur: on-site effects; off-site effects in nearby/adjacent land use types; and off-site effects in downstream locations.

i) On-site effects: within the exclosure itself

Exclosures improve the hydrology and soil inside the forested land in several ways: they prevent physical soil loss, maintain or increase soil water holding capacity, protect or increase top soil depth, prevent the loss of soil nutrient content and increase soil organic matter. These functions of exclosures improve soil quality within the forested land itself. The improvement in soil quality has a number of biophysical and socio-economic implications. As a result of improved soil quality and soil water content the total amount of biomass production will increase with subsequent ecological and economic benefits. Increased biomass production within the forested area and its economic value is one of the important on-site economic benefits of exclosures we deal with in this paper.

ii) Off-site effects: nearby/adjacent land use types

By improving the hydrology of catchments, besides the forested land, exclosures also have effects on land adjacent to them. The reduction in surface runoff may decrease the smothering of crops by sediments. Of course, there may be some possibilities that exclosures may contribute negatively to the nearby land use types, such as harboring rodents and pests that can damage crops and increased pressure on the remaining pasture. But from the practical point of view such negative effects are negligible in the study area and hence we do not consider these effects in the CBA.

iii) Off-site effects: downstream locations

By stabilizing the hydrological processes and regulating total water runoff and flooding, vegetation cover controls or reduces soil erosion and the problems of downstream sedimentation and siltation (Clark, 1996; Pattanayak and Mercer, 1996; Kramer et al., 1997; Pattayanak and Kramer, 2001; Pattayanak, 2004). The eroded sediments can be deposited in reservoirs and reduce hydroelectricity generation and water supplies for irrigation. Sediments can also reduce the operational efficiency of irrigation 
systems and impair the quality of drinking water. Because of their sediment trapping capacity, exclosures can prevent sediment loads from leaving the catchment and silting up water reservoirs. Vegetation restoration in exclosures also act as a 'sink' area where the incoming water infiltrates or deeply percolates beyond the root zones and contributes to the ground water recharge and induces new springs. The new water sources can be used, among other things, for irrigation. Reservoir sedimentation protection and new spring development are among the major downstream benefits of exclosures in the study area.

The major conceivable environmental benefits $(+)$ and damages $(-)$ in each of the three locations are listed below.

1) On- site: on the reforested area itself

- increase in soil fertility $(+)$

- increase in soil nutrient content $(+)$

- increase in soil moisture content $(+)$

- increase in depth of top soil (+)

- increase in soil organic matter content $(+)$

- increase in rain water infiltration (decrease in run-off) $(+)$

- increase in soil fauna population involved in nutrient recycling \& soil aeration $(+)$

- increase in wild life $(+)$

- enhanced biodiversity (+)

2) Off-site: in nearby/adjacent land use types

- increase soil moisture if infiltrated ground water flows to the crop land $(+)$

- harbor rodents, pests and other wild life that damage crops (-)

- decrease in flooding $(+)$

- decrease in the smothering of crops by sediments $(+)$

- less crop or grazing field $(-)$

3) Off-site (downstream) effects

- decrease in reservoir sedimentation( + )

- decrease in flood damage $(+)$

- increase in the probability of new spring up-coming $(+)$

- decrease in salinization effect $(+)$

- decrease in provision of fertile sediments that may increase yields downstream $(-)$

- decrease in supply of sand for building industry $(-)$

- reduction in the cost of drainage maintenance $(+)$

In addition to the effects presented above the following general externalities of exclosures were also identified.

- dust trapping, positive effect on community health ( + )

- carbon sequestration $(+)$

- climate regulation $(+)$

- drought mitigation effect $(+)$

- increasing pressure on the remaining pastures, which may lead to severe land degradation in other sites (-)

To facilitate the quantification and valuation of the various effects, the items listed above are consolidated to show the final outcome of their combined effects (see Fig. 1).

For instance, the items listed under the 'on-site: on the reforested area itself are all contributing to the improvement of soil and hydrology within the forested land which ultimately results in increase in biomass production. Therefore, the changes in biomass production induced by the 'set aside' land use policy were quantified and valued for the CBA.

\section{Materials and methods}

\subsection{Study area description}

Tigray is located in the northernmost region of Ethiopia between $12^{\circ} 15^{\prime} \mathrm{N}$ and $14^{\circ} 50^{\prime} \mathrm{N}$ and $36^{\circ} 27^{\prime} \mathrm{E}$ and $39^{\circ} 59^{\prime} \mathrm{E}$ and covers an area of approximately $53,000 \mathrm{~km}^{2}$ (Tesfay, 2006). It is a semi-arid zone characterized by a long dry period with a main rainy season between June and September. The province shares common borders with Eritrea in the north and Sudan in the west (Fig. 2). The rainfall distribution in the region is characterized by high spatial and temporal variability with annual precipitation ranging from 450 to $980 \mathrm{~mm}$ (Gebremedhin et al., 2004; Tesfay, 2006). Forest resources of the region were highly overexploited (TFAP, 1996; Tilahun et al., 2007).

The study site, Dogua Tembein district, with a total area of about $1110 \mathrm{~km}^{2}$ is situated in the central Tigray in the upper watershed of the Tekeze River, a tributary of the Nile River in northern Ethiopia. The average annual rainfall in the district ranges between 712 and $794 \mathrm{~mm}$ (Babulo, 2007). The temperature profile of the district's highlands shows little variations throughout the year, monthly maximum temperature ranges between 20 and $22^{\circ} \mathrm{C}$, monthly minimum temperature between 4 and $6{ }^{\circ} \mathrm{C}$. According to the traditional agroclimatic classification, the district's highland areas are situated in the zones of middle highlands (locally called 'woina dega') (15002300 m.a.s.l.) and upper highlands (locally known as 'dega') (23003200 m.a.s.l.) (Babulo et al., 2008). As part of the environmental rehabilitation and forest regeneration program, since the 1980's onward, about 11,924 ha (i.e., nearly $10 \%$ of the total area of the district) was closed from human and livestock intervention (Balana et al., 2010). Exclosures in the study district vary both in age of establishment and size. In terms of age, closed areas are distributed with a mean age of 13 and standard deviation of 4.6 years. The size distribution has got a mean of 50 and a standard deviation of 92 ha (Babulo, 2007).

Like that of the national economy, agriculture is the main source of livelihood in the study district. The farming system can be classified as mixed crop and livestock subsistence farming. A mixed wheat and barley variety (locally called 'hanfets'), wheat (Triticum aestivum), teff (Eragrostis tef), barley (Hordeum vulgare), and horse bean (Vicia faba) are the main crops grown in the area, respectively accounted for $35 \%, 20 \%, 19 \%, 10 \%$, and $4 \%$ of the cultivated land in the $2004 / 05$ main cropping season (Babulo, 2007). Sales of livestock (mainly small ruminants) and livestock products are important sources household's cash income. Sale of firewood as source of cash income is also practiced widely in the study area.

\subsection{The $\mathrm{data}^{3}$}

The data used in this study were collated from various previous studies in Tigray on soil erosion, sedimentation, hydrology, forestry, biomass production and agronomy and organized in a database, structured according to the on-site and off-site effects of exclosures. Reservoir sedimentation and sediment yield data were based on Haregeweyn et al. (2006). Data on sediment trapping efficiency of exclosures were obtained from Descheemaeker et al. (2006). Estimation of potential new spring development was based on Descheemaeker (2006). Water productivity and incremental yield were based on field experimental work of Behailu et al. (2007). Data on the calculation of biomass production come from various previous works in the study area and elsewhere in Ethiopia (Newcombe, 1987; TFAP, 1996; Jagger and Pender, 2003; Cleemput, 2003; Roebben, 2004; Tilahun et al., 2007; Mekuria et al., 2007). Age and size distribution of exclosures was obtained from the office of the Relief Society of Tigray (ReST), a local NGO operating in the area. Expert estimates ${ }^{4}$ were also obtained to supplement the data and fill the gaps where crucial information was lacking.

\footnotetext{
${ }^{3}$ All the monetary figures (i.e, cost and price figures) used in this study were adjusted to the 2006 prices (i.e. $2006=100$ ).

${ }^{4}$ Expert estimates were obtained from a number of researchers who conducted studies on various issues such as soil, hydrology, forestry, and erosion in the study area (three forest ecology experts, two soil and water conservation experts, a forest economist, a soil erosion specialist, and a geographer were involved in providing the various estimates).
} 
- Increase in soil fertility: (on-site)

- Increase in soil nutrient content: (on-site)

- Increase in soil moisture content: (on-site)

- Increase in depth of top soil: (on-site)

- Increase in soil organic matter: (on-site)

- Increase in rain water infiltration (decrease in runoff): (on-site)

- Increase in soil biological activity involved in nutrient cycling and soil aeration: (on-site)

- New spring development: (off-site)

- Increase in soil moisture: (off-site)

- Decrease in flooding: (off-site)

- Decrease in smothering of crops by sediments: (off-site)

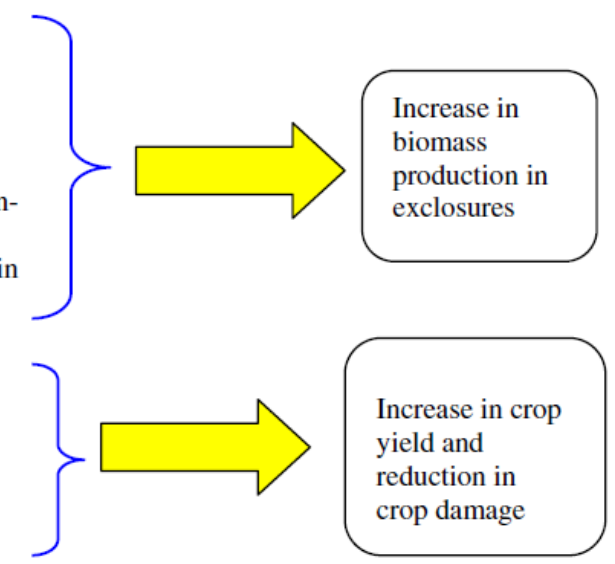

- Decrease of damage to reservoirs storage volume: (off-site)

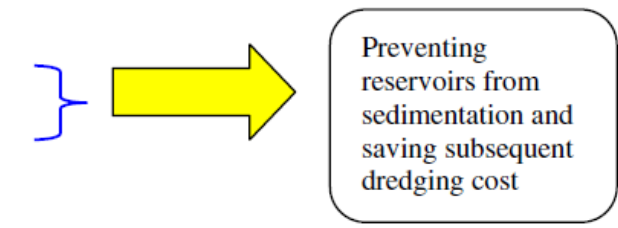

- Loss of land area for cropping or grazing

- Labor cost in protecting or guarding exclosures

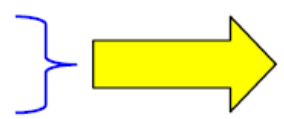

Opportunity cost of land and labour

Fig. 1. Conceptual scheme of soil and water conservation effects of exdosures. Left: consolidated list of the effects of exclosures (on-site or off-site in brackets). Right: ultimate benefits or costs attributed to establishment of exclosures.

Data on construction costs of reservoirs were obtained from the project document of Sustainable Agriculture and Environmental Rehabilitation in Tigray (SAERT, 1994). In order to account for the effect of changes in prices over time cost figures were adjusted to the 2006 prices using appropriate national price indices. Local market prices

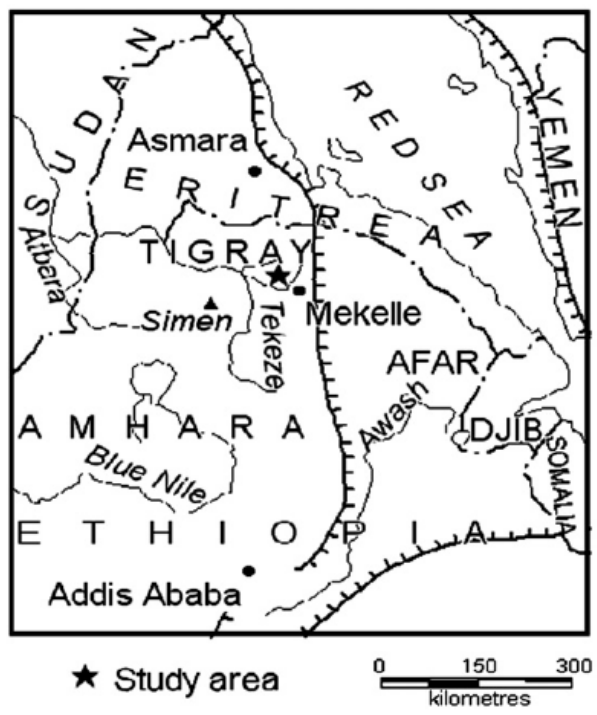

Fig. 2. Location of the study area in the northern Ethiopia. for biomass products and crops were obtained from the District's Office of Agriculture.

\subsection{Quantification and valuation of benefits and costs}

On the basis of Fig. 1, four broad categories of benefit items and two major cost items were considered in the CBA. The benefit items comprise biomass production, reservoir sedimentation protection, protecting crop fields from flood damage and irrigation potential of new springs. The two major cost items are the opportunity cost of land and labor. Quantification and valuation of each of these benefit and cost items are described below.

\subsubsection{Biomass production in exclosures}

As indicated in Fig. 1, changes in soil nutrients and hydrology induce the production of more biomass (both woody and herbaceous).

Woody biomass: On the basis of the available literature and expert estimates, the following assumptions were made to quantify the potential level of sustainable woody biomass harvest from exclosures.

a. Woody biomass harvest is zero in the first five years of the establishment of exclosures. This is a regeneration period and people have to wait for five consecutive years to start the first harvest (see footnote 6).

b. In the sixth year the mean annual increase (MAI) allows a sustainable harvest of $0.733 \mathrm{t} / \mathrm{ha}^{5}$ (TFAP, 1996). In response

\footnotetext{
${ }^{5}$ This figure is according to the estimate of Tigray Forestry Action Program (TFAP,
} 1996) for woodland. 
to the accumulation of more nutrients and increasing water infiltration over time within exclosures, the rate of plant growth increases each successive year till it reaches some maximum MAI. We assumed that from year six onward the MAI increases at a rate of $10 \%$ every year till it reaches a maximum of $1.2 \mathrm{t} / \mathrm{ha}$ in year 11 and thereafter remains constant at $1.2 \mathrm{t} / \mathrm{ha}^{6}$

c. To allow increase in the growing stock of the resource system in successive years, the annual allowable cut should be set lower than the annual increment. Thus, we assume that out of the annual woody biomass increment, $2 / 3$ is harvested for human use and $1 / 3$ is left to allow the stock to increase. ${ }^{7}$ Accordingly, the annual harvest of woody biomass will be $0.49,0.54,0.60,0.66$, and $0.72 \mathrm{t} / \mathrm{ha}$ in years $6,7,8$, 9 , and 10 respectively. In year 11 and onward the volume of annual harvest will remain at $0.804 \mathrm{t} / \mathrm{ha}$.

d. The woody biomass harvested is utilized as fuel wood (i.e., valuation is based on use of woody biomass as fuel wood). This is a realistic assumption in the context of Ethiopia, particularly in Tigray where $95 \%$ of total demand for wood and woody biomass in rural areas is for fuel wood (Eshete, 1999; Jagger and Pender, 2003).

e. Institutional barriers that may hinder households' access to exclosures were not considered while estimating the volume of woody biomass harvested. Thus, our estimate reflects the potential sustainable benefit as the actual harvest may be constrained by institutional barriers such as local rules of harvest restriction.

f. As woody biomass is a readily marketable product in the study area, we used the farm-gate price of fuel wood to value woody biomass products.

Grass biomass: On the basis of herbaceous biomass estimation study conducted in exclosures of various ages in the study area or elsewhere in Tigray (Tilahun et al., 2007; Descheemaeker (pers. comm., 2007); Cleemput, 2003), the estimates and trends of herbaceous biomass production were derived:

a. At the end of first year $1.11 \mathrm{t} / \mathrm{ha}$ is produced (Cleemput, 2003).

b. Up to the fifth year $40 \%$ annual increment is assumed till it reaches the highest level in year 5 . Therefore, grass production becomes $1.54 \mathrm{t} / \mathrm{ha} ; 1.99 \mathrm{t} / \mathrm{ha} ; 2.44 \mathrm{t} / \mathrm{ha}$; and $2.85 \mathrm{t} / \mathrm{ha}$ in the $2 \mathrm{nd}, 3 \mathrm{rd}, 4$ th, and 5 th years respectively.

c. Due to an increasing dominance of tree biomass, grass production tends to decrease from year six onward. We assume a 20\% annual reduction till it reaches a sustainable harvest level of $1.01 \mathrm{tha}^{-1}$ year $^{-1}$ in year 10 . From year 10 onward the $1.01 \mathrm{tha}^{-1}$ year $^{-1}$ amount of grass is constantly harvested.

d. We assumed that some specific tree management schemes such as pruning or thinning are practiced to allow a sustainable annual harvest such that grass production will be continued as exclosures get older.

\subsubsection{Prevention of reservoir sedimentation}

Seasonal runoff water harvesting via earth dams and ponds has been widely practiced in Tigray in small and medium scale irrigated agriculture, which is considered to be an important component of a long-term food security strategy. One of the major obstacles to this

\footnotetext{
${ }^{6}$ Ethiopian Forestry Action programme (EFAP, 1993; cited in Jagger and Pender, 2003) has estimated an MAI of $1.2 \mathrm{tha}^{-1} \mathrm{year}^{-1}$ for natural woodland in Ethiopia. See also TFAP (1996, p. 45). In TFAP (1996) the average mean annual incremental per hectare for natural forests, woodlands, bush lands, and shrub lands is approximately estimated at $1.12 \mathrm{~m}^{3} / \mathrm{ha} /$ year. Mekuria et al. (2007, p. 279) have estimated a MAl of biomass in exclosures ranging from 0.70 to $1.05 \mathrm{tha}^{-1}$ year $^{-1}$.

${ }^{7}$ This was based on expert estimates (Descheemaeker (pers. comm., 2007); Mekuria (pers. comm, 2007)).
}

scheme is sediment deposition in the reservoirs that shortens the life span of reservoirs (Haregeweyn et al., 2006). By trapping the incoming sediments and stabilizing soil particles within the exclosures, vegetation cover counteracts the problem of reservoir sedimentation. This protective service has an important economic value in terms of avoiding the periodic maintenance cost or maintaining the life of the reservoirs for profitable economic activities.

The maximum potential benefit occurs if exclosures of sufficient size and vegetation cover are assumed to exist in appropriate locations and distance (nearby to the reservoirs), such that all the incoming sediments can be trapped. In such a scenario the problem of sedimentation can be fully resolved. On the other hand, one can hypothesize an inverse relationship between distance and the effect of exclosures in protecting reservoir sedimentation, i.e., the farther the location of exclosures from reservoirs the less effective the exclosures in protecting reservoir sedimentation.

The replacement cost approach was employed in estimating the economic value of the function of exclosures in reducing reservoirs sedimentation. Accordingly, the annual cost that would have been spent on maintaining the storage capacity of reservoirs was used to infer the economic value of sedimentation protection services of vegetation in exclosures. Assuming that exclosures are capable of trapping the incoming sediments and utilizing data of Appendix 1, the following procedures were pursued:

a) Divide the digging cost of a typical reservoir (ETB 1.75 million $)^{8}$ by the total storage volume of an average reservoir $\left(0.828 \times 10^{6} \mathrm{~m}^{3}\right)$ (see Appendix 1). This gives ETB $2.12 \mathrm{~m}^{-3}$ as the unit digging cost for a cubic meter $\left(\mathrm{m}^{3}\right)$ of the reservoir (denote this $C C_{\text {unit }}$ ).

b) Convert the weighted average mass of sediment deposited in a hectare of exclosure ( $48.6 \mathrm{tha}^{-1}$ year $^{-1}$ ) to volume using the average bulk density $\left(1.24 \mathrm{t} \mathrm{m}^{-3}\right.$ ) (see Descheemaeker, 2006). This computation gives $39 \mathrm{~m}^{3}$ as the volume of sediments trapped in a hectare of exclosure in a year (denote this Sedd vol. $_{\text {. }}$.

c) Multiplying $C C_{\text {unit }}$ (assuming that removing the silted sediments would cost equivalent amount of money to the initial excavation cost) by the volume of sediments trapped in hectare of an exclosure ( $\operatorname{Sedd}_{\text {vol. }}$ ), we obtain ETB 83 as an estimate of the annual per hectare value of exclosure with respect to reservoir protection service. Therefore, $V_{\text {Prot. Sed }}=C C_{\text {unit }} \times S e d d_{v o l}$, where $V_{\text {Prot.Sed }}$ is the reservoir sedimentation protection service of a hectare of exclosure per annum and $C C_{\text {unit }}$ and $S e d d_{v o l}$ are as defined above.

\subsubsection{Reduction in flood damage of crop land}

Here, we attempt to estimate the economic value of the potential damage of crop yield if exclosures were not established in the upland above crop fields. Anecdotal evidence from the study area shows that out of the total area of exclosures in the study district $(11,924 \mathrm{ha})$, more than half are located in upland areas adjacent to crop fields (Descheemaeker, pers. comm.). On the basis unpublished data from the District's Agricultural Office, about $60 \%$ of the total available exclosures (i.e. about $7154 \mathrm{ha}$ ) is supposed to be located above crop fields. Taking the 50 ha average exclosure size, we obtain 143 different exclosures protecting crop land from flood damage. Exclosures in the study district usually follow the contour lines over long distances with about 100 to $150 \mathrm{~m}$ width. This implies that each exclosure has a length between 3.33 and $5 \mathrm{~km}$. This would result in total length of 477 to $715 \mathrm{~km}$ vegetation belt subject to crop field protection from flooding. However, all farm fields are not equally susceptible to flood damage. We assume that in the absence of the vegetation buffers, crop fields adjacent to the closed areas up to $100 \mathrm{~m}$ wide are subject to the damage (full damage in the first $50 \mathrm{~m}$ width and $50 \%$ damage in the next $50 \mathrm{~m}$ width). Provided that the width condition is satisfied and using the

\footnotetext{
${ }^{8}$ ETB = Ethiopian Birr (the legal Ethiopian currency). At the time of drafting this paper (March, 2007) the exchange rate was US\$ $1=$ ETB 9.16.
} 
estimated crop value of ETB $689 \mathrm{ha}^{-1}$, it can be shown that had exclosures not been established annual crop yield worth of ETB 43 would have been lost by flood damage against each hectare of exclosure.

4.3.4. New spring development and its irrigation potential

Another important function of vegetation restoration in exclosures is acting as a 'sink' area for incoming water. Using the BUDGET soil water balance model developed by Raes et al. (2006), Descheemaeker (2006) investigated the effect of vegetation restoration on the components of the soil water balance. Vegetation restoration in exclosures induces increased infiltration of incoming water. The infiltrated water that remains in excess supply (not utilized by plants) percolates deeply beyond the root zone and contributes to ground water recharge and induces development of new springs. In this regard, a practical example in the study area is the 'Mai-zeg-zeg integrated watershed project' initiated in 2001 in Tigray. Influenced by exclosures and other related soil and water conservation measures at the Mai-zeg-zeg watershed in Tigray, new springs have been originated and the surrounding community developed small scale irrigation schemes to grow cash crops such as onion and garlic. To estimate the monetary value of this particular ecosystem service of exclosures we pursued the following steps.

a) Estimation of the amount of water production from a unit area of exclosure:

This estimate was based on the field measurement and simulation analyses of Descheemaeker (2006). Using simulation analysis for different scenarios of land use types and rainfall situations, Descheemaeker has examined the effect of vegetation restoration on water balance components in the Tigray highlands. With the help of these data we estimated the volume of water produced from a hectare of exclosure readily available for irrigation.

b) Estimation of water productivity and incremental yield: In arid and semi-arid areas, such as Tigray, agricultural productivity is seriously hampered by moisture stress. Using maize as an indicator crop and experimental data from two irrigation seasons, Behailu et al. (2007) estimated that the average water productivity in Tigray is $0.62 \mathrm{~kg} \mathrm{~m}^{-3}$. Based on this estimate and data on the average yield of maize in rain-fed agriculture in the study area, we estimated the potential incremental yield influenced by availability of more water.

c) Estimation of the value of incremental crop output:

Using the variable cost of production estimates from Behailu et al. (2007) and the local market price of maize, the net value of incremental yield is computed.

d) Deriving value estimates for the incremental yield induced by water produced per ha of exclosure: This estimate was derived by multiplying the volume of water produced from a hectare of an exclosure (obtained in step (a) above) and the net incremental value of water productivity (obtained in step (c) above).

\subsubsection{Scenarios of land productivity and its opportunity cost}

If highly productive land is taken out of its current use (say crop production) for woodland development, there will be a significant cost related to the forgone crop production. Conversely, it is intuitive that if less productive marginal lands are set aside for natural regeneration of trees, society incurs quite little cost as a result of land reallocation. Available evidence indicates that the majority of exclosures in the study area were established on steep degrading grazing land (TFAP, 1996; Descheemaeker et al., 2006). To be able to compare the forgone economic costs of various land units converted to exclosures, we considered the following three potential land productivity scenarios:

Scenario 1 (less productive land): Here we assumed lands converted to exclosures were less productive marginal lands with meager opportunity cost. In many instances the opportunity cost of such marginal lands may appear insignificant. On the basis of anecdotal information from local land users and the District's Agricultural Office, we assumed the opportunity cost for such lands is $10 \%$ of the estimated value of productive crop land.

Scenario 2 (semi-productive land): Under this scenario we want to examine the economic return of the conversion from cultivable semiproductive lands to forest land. Following Jagger and Pender (2003) we assumed the opportunity cost of semi-productive land to be $1 / 3$ of the estimated value of productive crop land.

Scenario 3 (productive crop land): In this scenario we were interested to analyze whether converting productive crop lands to forest land has positive economic returns. Here the opportunity cost of a hectare of land was equated with the net crop revenue per hectare (Jagger and Pender, 2003).

\subsubsection{Labor cost}

The only labor cost we considered here is the periodic payment for guards. Since exclosures are being implemented primarily as a setaside conservation measure on common grazing lands and community woodlands and let for natural vegetation regeneration and protected by locally hired guards, labor cost for planting and maintenance can be assumed zero. Fences or other mechanical measures were not applied to protect these areas. Therefore, zero establishment costs of labor and material inputs were a realistic assumption. The national minimum wage rate for unskilled labor was taken as the opportunity cost of labor engaged in guarding activity. Harvesting and tree management costs were not accounted for; because some specific tree management activities, such as pruning and thinning are normally undertaken in slack periods and collection cost of forest products (for example fuel wood) would be quite high in the absence of exclosures.

\subsection{Framework for decision-making}

We employ the net present value (NPV) decision criterion in comparing the economic profitability of alternative land uses. NPV is defined as the difference between the sum total of the present value of discounted benefit streams and the discounted value of cost streams over the life of the project (Eq. (1)). According to the NPV criterion projects with non-negative NPV are accepted and projects with negative NPV are rejected. It is also the preferred selection criterion to choose among mutually exclusive projects (Gittinger, 1982):

$N P V=\frac{\sum_{t=0}^{T} B_{t}}{(1+d)^{t}}-\frac{\sum_{t=0}^{T} C_{t}}{(1+d)^{t}}=\sum_{t=0}^{T}\left[\left(B_{t}-C_{t}\right)(1+d)^{-t}\right]$

where:

NPV net present value (ETB/ha)

$B_{t} \quad$ benefit at time ' $\mathrm{t}$ ' $(\mathrm{ETB} / \mathrm{ha})$

$C_{t} \quad$ cost at time ' $\mathrm{t}$ ' (ETB/ha)

$d$ the discount rate

$t \quad$ time in years $(t=1,2, \ldots T)$

In the context of the study area, loan interest rates range from 15\% of the local microfinance institute to $50 \%$ or even more of informal local money lenders. For appraising public investment projects in Ethiopia the national discount rate used is $10 \%$. Though there exists excess local demand for credit even at $15 \%$ interest rate neither of these rates are appropriate for evaluating environmental projects. Taking the nature of the environmental project into account and with consultation of the local Bureau of Natural Resources and Environmental Protection, we opted to apply an $8 \%$ discount rate (i.e. almost half of the local market rate).

The period of time the economic analysis of the project is carried out is another important parameter that has to be chosen. As the economic 
life of the environmental project under investigation - exclosures - is ambiguous, the time period for the analysis is based on the influence of the discount rate on the economic significance of the future flow of benefits and costs. Due to discounting, future values become less and less important as the time period gets longer and longer. From an environmental point of view this may not be a valid argument. From the point of view of CBA the present worth of future values beyond 30 years make no significant difference in the results of the analysis. For instance, at $8 \%$ and $15 \%$ discount rates, ETB 1 thirty years from now has a present value of ETB 0.099 and ETB 0.015 respectively. At higher discount rates the present value will be much lower. Therefore, we chose 30 years in our analysis. The base year value estimates of the cost and benefit items used in CBA are presented in Table 1. Possible changes in value estimates and the resulting NPV due to changes in various parameters (increases or decreases) were investigated in sensitivity analyses.

\section{Results}

\subsection{Base case NPV estimates}

The estimates of undiscounted net benefits (NB) and net present values (NPV), assuming different opportunity cost of land, are presented in Table 2. If degraded less productive land units are converted to exclosures the annual net returns are positive throughout the life of the project and the NPV is also large and positive (NPV=ETB $5620 / \mathrm{ha}$ ). As the opportunity cost of land is the major trade-off that society forgoes in establishing exclosures, the positive NB and NPV are a priori expected and intuitive when a very low opportunity cost is assigned to land. Then the next key question would be whether benefits from exclosures could compensate social costs when land units with increasing positive opportunity costs are converted to forests. The last two columns in Table 2 throw some light on this inquiry.

When partially degraded semi-productive land is converted to exclosures, though the net benefits are very low in the initial periods, the overall NPV is still positive and large (NPV=ETB 3031/ha). However, converting productive crop land to forests results in a negative net present value (NPV $=\mathrm{ETB}-2135 / \mathrm{ha})$. It is thus uneconomical to introduce land use change from productive crop lands to forest land.

Table 3 presents the discounted values of each benefit item included in the analysis. The results give us some indication of the relative importance of the various benefit items in the overall NPV. Comparing the relative share of on-site and off-site effects in total present value of benefits (PVB), 58\% of the total PVB is accounted for by on-site benefits and the remaining $42 \%$ by off-site benefits. Among the benefit items, the discounted value of grass products accounts for the largest share and woody biomass in the form of fuel wood occupies the second position. However, previous studies show that fuel wood shortage is a serious problem in the study area (Newcombe, 1987; TFAP, 1996). So, by taking

Table 1

Value estimates of the benefit and cost items used in net present value calculation.

\begin{tabular}{ll}
\hline Item & value estimate \\
\hline Woody biomass (fuel wood) & ETB $300 \mathrm{t}^{-1}$ \\
Herbaceous biomass (grass) & ETB $120 \mathrm{t}^{-1}$ \\
Protection of reservoir sedimentation & ETB $83 \mathrm{ha}^{-1} \mathrm{year}^{-1}$ \\
Protection of crop field from flooding damage & ETB $43 \mathrm{ha}^{-1} \mathrm{year}^{-1}$ \\
New spring irrigation potential (young exclosure) & ETB $79 \mathrm{ha}^{-1} \mathrm{year}^{-1}$ \\
New spring irrigation potential (middle-aged exclosure) & ETB $120 \mathrm{ha}^{-1} \mathrm{year}^{-1}$ \\
New spring irrigation potential (old exclosure) & ETB $114 \mathrm{ha}^{-1} \mathrm{year}^{-1}$ \\
Opportunity cost of productive crop land & ETB $689 \mathrm{ha}^{-1} \mathrm{year}^{-1}$ \\
Opportunity cost of semi-productive land & ETB $230 \mathrm{ha}^{-1} \mathrm{year}^{-1}$ \\
Opportunity cost of less productive land & ETB $69 \mathrm{ha}^{-1} \mathrm{year}^{-1}$ \\
Cost of labor service in guarding & ETB $48 \mathrm{ha}^{-1} \mathrm{year}^{-1}$ \\
\hline
\end{tabular}

Table 2

Net present value (ETB/ha) for the changing opportunity cost of land at $8 \%$ discount rate.

\begin{tabular}{lllllll}
\hline $\begin{array}{l}\text { Year } \\
(\mathrm{t})\end{array}$ & $\begin{array}{l}\mathrm{NB}^{(\mathrm{OCLL})}(\mathrm{t}) \\
(\mathrm{A})\end{array}$ & $\begin{array}{l}\mathrm{NB}^{(\mathrm{OClS})}(\mathrm{t}) \\
(\mathrm{B})\end{array}$ & $\begin{array}{l}\mathrm{NB}^{(\mathrm{OCLP})}(\mathrm{t}) \\
(\mathrm{C})\end{array}$ & $\begin{array}{l}\mathrm{NPV}^{(\mathrm{A})}(\mathrm{t}) \\
(\mathrm{D})\end{array}$ & $\begin{array}{l}\mathrm{NPV}^{(\mathrm{B})}(\mathrm{t}) \\
(\mathrm{E})\end{array}$ & $\begin{array}{l}\mathrm{NPV}^{(\mathrm{C})}(\mathrm{t}) \\
(\mathrm{F})\end{array}$ \\
\hline 1 & 290.20 & 60.20 & -398.80 & 268.73 & 55.75 & -369.29 \\
2 & 341.80 & 111.80 & -347.20 & 292.92 & 95.81 & -297.55 \\
3 & 395.80 & 165.80 & -293.20 & 314.27 & 131.65 & -232.80 \\
4 & 499.80 & 219.80 & -239.20 & 330.60 & 165.55 & -175.81 \\
5 & 499.00 & 269.00 & -190.00 & 339.82 & 183.19 & -129.39 \\
6 & 618.80 & 388.60 & -70.40 & 389.72 & 244.82 & -44.35 \\
7 & 578.40 & 384.40 & -110.69 & 337.21 & 203.12 & -64.50 \\
8 & 553.20 & 323.20 & -135.80 & 298.73 & 174.53 & -73.33 \\
9 & 336.40 & 306.40 & -152.60 & 247.80 & 153.20 & -76.30 \\
10 & 535.20 & 305.20 & -153.80 & 240.41 & 141.31 & -71.21 \\
$11-30^{\mathrm{a}}$ & 11,118 & 6518 & -2662 & 2292 & 1486 & -601 \\
Total $^{\mathrm{b}}$ & 15,916 & 9016 & -4754 & 5620 & 3031 & -2135 \\
\hline
\end{tabular}

' $t$ ' $=$ the time period in years $(t=1,2, \ldots 30) ; \mathrm{OLC}=$ opportunity cost of land; $\mathrm{NB}(\mathrm{OCLL})$ $(\mathrm{t})=$ undiscounted net benefit when the opportunity cost of less productive land is considered; $\mathrm{NB}(\mathrm{OCLS})(\mathrm{t})$ = undiscounted net benefit when the opportunity cost of semi-productive land is considered; $N B(O C L P)(t)=$ undiscounted net benefit when the opportunity cost of a productive land is considered; $\operatorname{NPV}(A)(t)=$ the NPV computed under $(A) ; N P V(B)(t)=$ the NPV computed under $(B) ; \operatorname{NPV}(C)(t)=$ the NPV computed under (C).

a Annual amount for years 11 through 30 inclusive; to calculate the column total, this amount must be included 20 times.

b The sums are rounded to zero decimal place.

the relative importance of fuel wood in the study area, one may cast doubt on our findings that give more weight to grass products rather than woody biomass.

Two explanations could be provided. First, taking the slow natural regeneration of tree species into account, we formulated our problem by assuming zero woody biomass harvest in the initial periods. To allow the stock increment of the resource system over time, we further assumed that a certain proportion of the mean annual increment (MAI) of woody biomass is not harvested for human use. For grass products, however, such restrictions were not imposed. Second, discounting makes distant future values less important in present terms. A comparison of undiscounted values reveals the total value of woody biomass per hectare of exclosure is larger than that of grass value. Larger NPV of herbaceous biomass in the discounted form reflects the effect of discounting. Findings similar to ours were also documented by other researchers. For instance, Tilahun et al. (2007) have found that in a closed site in Tanqua Abergelle district of Tigray nearly $95 \%$ of the NPV is attributable to grass production whereas frankincense products accounted for only about $5 \%$ of the NPV.

The off-site benefits of vegetation restoration in exclosures exhibit important environmental services evidenced by the net present values estimated for new spring development and its potential for irrigation, reservoirs protection from sedimentation, and crop field protection from flooding damage. These ecological services respectively account for $19 \%, 15 \%$ and $8 \%$ of the total present value of exclosures' benefits. To the best of our knowledge to-date no studies have

Table 3

Present value estimates (ETB/ha) for base scenario (by benefit items, $8 \%$ discount rate).

\begin{tabular}{lc}
\hline Benefit items & PVB $^{\text {a }}$ (ETB/ha) \\
\hline Woody biomass (on-site benefit: on forested area) & 1580 \\
Grass (on-site benefit: on forested area) & 1991 \\
Crop field protection from flooding (off-site: adjacent areas) & 484 \\
Reservoir sedimentation protection (off-site: downstream effect) & 934 \\
New spring potential for irrigation (off-site: downstream effect) & 1170 \\
Total & 6160 \\
\hline
\end{tabular}

${ }^{a}$ PVB $=$ present value of benefit. 
estimated the economic value of ecological services provided by vegetation restoration in the Tigray. Therefore, our findings shed an important light on the 'hidden' environmental values of vegetation in exclosures.

\subsection{Sensitivity analysis}

Usually the quantities and values of the benefit and/or cost items and the economic parameters used in the analysis may undergo changes over time. Such uncertainties of future circumstances affect the results of the CBA. Therefore, it is common to rework the analysis to see what happens under the changed circumstances. Reworking the analysis to test the project's volatility to changes in one or more of the values or parameters of the project is known as sensitivity analysis (Table 4).

In this study we considered three possible areas of change and investigated the sensitivity of the base case results for various changes. Changes in quantity of the various benefit and cost items, changes in prices or values of the various cost and benefit items, and changes in the discount rate were treated in the sensitivity analysis. Specifically changes in the following parameters were introduced: discount rate, quantity of woody biomass, price of woody biomass, price of grass and value estimates of all benefit items. Due to a lack of historical records, we were not able to trace the empirical volatility of these parameters. Hence, some possible changes are assumed and the results are presented in Table 4.

Table 4 summarizes the impact of changes of some key parameters on NPV estimates with varying opportunity cost of land. Changes in the opportunity cost of land and the social discount rate have strong influences on the NPV. Other things remain the same and with zero opportunity cost for land, a $50 \%$ increase in social discount rate from the base case (i.e., from $8 \%$ to $12 \%$ ) causes a $31 \%$ fall in NPV. On the other hand a decrease in discount rate by $50 \%$ (from $8 \%$ to $4 \%$ )

Table 4

Sensitivity analysis of various parameters of the NPV of exclosure establishment.

\begin{tabular}{|c|c|c|c|c|}
\hline \multirow[t]{3}{*}{ Parameter } & \multicolumn{4}{|c|}{ Changes in parameters } \\
\hline & $+50 \%$ & $+25 \%$ & $-25 \%$ & $-50 \%$ \\
\hline & $\mathrm{NPV}_{1}$ & $\mathrm{NPV}_{2}$ & $\mathrm{NPV}_{3}$ & $\mathrm{NPV}_{4}$ \\
\hline \multicolumn{5}{|c|}{$\begin{array}{l}\text { Scenario 1: less productive land }\left(O C L=E T B 69 \mathrm{ha}^{-1} \text { year }^{-1} \text { ) }\right. \\
\text { (Base case and OCLL, NPV }=5620 \mathrm{ETB} / \mathrm{ha} \text { ) }\end{array}$} \\
\hline Discount rate & 3888 & 4623 & 6983 & 8914 \\
\hline Quantity of woody biomass & 6410 & 6015 & 5225 & 4830 \\
\hline Price of woody biomass & 6410 & 6015 & 5225 & 4830 \\
\hline Price of grass & 6616 & 6118 & 5122 & 4624 \\
\hline Value estimates of all benefit items & 8700 & 7160 & 4080 & 2540 \\
\hline \multicolumn{5}{|c|}{$\begin{array}{l}\text { Senario2: semi-productive land }\left(O C L=E T B 230 \mathrm{ha}^{-1} \text { year }\right. \\
\text { (Base case and OCLS, NPV }=3031 \mathrm{ETB} / \mathrm{ha})\end{array}$} \\
\hline Discount rate & 2035 & 2457 & 3820 & 4940 \\
\hline Quantity of woody biomass & 3821 & 3426 & 2636 & 2241 \\
\hline Price of woody biomass & 3821 & 3426 & 2636 & 2241 \\
\hline Price of grass & 4027 & 3529 & 2533 & 2035 \\
\hline Value estimates of all benefit items & 6111 & 4571 & 1491 & -49 \\
\hline \multicolumn{5}{|c|}{$\begin{array}{l}\text { Scenario 3: productive land }\left(\mathrm{OCL}=E T B 689 \mathrm{ha}^{-1} \text { year }^{-1} \text { ) }\right. \\
\text { (Base case and OCLP, NPV }=-2135 \mathrm{ETB} / \mathrm{ha} \text { ) }\end{array}$} \\
\hline Discount rate & -1664 & -1867 & -2494 & -2992 \\
\hline Quantity of woody biomass & -1345 & -1740 & -2530 & -2925 \\
\hline Price of woody biomass & -1345 & -1740 & -2530 & -2925 \\
\hline Price of grass & -1140 & -1638 & -2633 & -3131 \\
\hline Value estimates of all benefit items & 944 & -595 & -3647 & -5216 \\
\hline
\end{tabular}

$\mathrm{OCL}=$ opportunity cost of land; $\mathrm{OCL}=$ opportunity cost of less productive land; $\mathrm{OCLS}=$ opportunity cost of semi-productive land; OCLP = opportunity cost of productive land; NPV1,NPV2, NPV3, and NPV4 are net present values when the parameter rises by $50 \%$, and $25 \%$, falls by $25 \%$ and $50 \%$ respectively. increases the NPV by 59\%, ceteris paribus. Changes in the opportunity cost of land alone (e.g., from less productive to semi-productive land), at the base discount rate of $8 \%$ and holding all other things the same, results in a $36 \%$ fall in the NPV. The trade-off that society bears by converting productive cropland to forestry could not be compensated even with the assumption of higher biomass production or higher prices of biomass products or lower social discount rate than the base case (see Table 4). The negative NPVs of the last five rows of Table 4 demonstrate this fact. Irrespective of the possible changes introduced to the selected parameters the NPVs remain negative throughout if the land reallocated for exclosures is productive cropland.

The NPV is more sensitive to changes in the price of grass than equivalent changes in the price or quantity of woody biomass. For instance, under scenario 1 (Table 4) an increase in the price of grass products by $50 \%$ increases the NPV by about $18 \%$ but an equivalent rise in the price of woody biomass increases NPV by $14 \%$. If the values of all benefit items change NPV becomes highly sensitive. A fall in value estimates of all benefit items by $50 \%$ decreases NPV by $55 \%$ (see scenario 1 in Table 4). However, in scenario 2 (see Table 4) the same percentage fall in value estimates of all benefits will result in a negative net present value (NPV $=\mathrm{ETB}-49)$.

We have also tested the sensitivity of NPV per hectare to changes in labor cost for guarding, sedimentation and flood protection values. We found that changes in these parameters showed very little effect on NPV and thus these are not reported in Table 4.

\section{Scaling up results}

Scaling up the estimated NPV of a hectare of exclosure to the total land area put under exclosures in the study district enables us to visualize the benefits of vegetation restoration in exclosures at the district level. Three important factors have to be considered before such an aggregation:

1) The land use type before its conversion to exclosures: The productivity of land in alternative economic activities is an important element in NPV computation. Following the three land productivity scenarios identified earlier (see Section 4.3.5), the following cases are proposed in order to estimate the NPV at district level. We suppose that out of the total land area reallocated for exclosures in the district:

Case 1: $10 \%$ crop land, $75 \%$ semi-productive land, and $15 \%$ less productive land

Case 2 : $0 \%$ crop land, $40 \%$ semi productive land, and $60 \%$ less productive land

2) Spatial distribution of exclosures: The location and distance of established exclosures relative to some other land use types determine the importance of an exclosure with regard to some specific environmental services. For instance, an exclosure protects crop land from flood damage if it is located in adjacent upslope area relative to the crop land. Similarly, the larger the distance between an exclosure and a reservoir, the less its effect on protecting the reservoir sedimentation. However, detailed geo-referenced quantitative data were not available. Thus, the scaling up exercise with regard to the distribution of exclosures subject to various environmental services was based on the description presented in Section 4.3.

3) Temporal aspect of exclosures: Temporal variations (ages of exclosures) also influence the environmental benefits. Obviously recent establishments and areas closed for decades do not have the same effects. However, the temporal variations have already been taken into account while quantifying and valuing the various benefit items.

Incorporating the prior land uses (cases 1 and 2 above) and spatial distribution of exclosures and the earlier three scenarios into our 
calculus we can compute the aggregate NPV for all closed areas in the district using Eq. (2).

$N P V_{\text {agg. }}=\sum_{i} \sum_{p} L_{p} N P V_{p} \times A_{i} \times R_{i}$

\section{where}

$N P V_{\text {agg. }}$ aggregated net present value for all closed areas

$L_{p} \quad$ proportion of different qualities of land converted to exclosures

$N P V_{p} \quad$ net present value computed corresponding to each land quality

$A_{i} \quad$ exclosure area (in ha) subject to the particular benefit item(s)

$R_{i} \quad$ proportion of the PVB of a particular benefit item in total PVB.

Using Eq. (2) an aggregate estimate of the NPV ranges from ETB 18.3 million to ETB 27.6 million (for cases 1 and 2 respectively). Institutively this result indicates that the larger the proportion of less productive land converted to forestry the greater would be the aggregate NPV. In the best case scenario where all the land put under exclosures was degraded land, $N P V_{\text {agg. }}$ increases to ETB 35 million. Assuming that the aggregate NPV is equally distributed over years, the annual NPV ranges from ETB 0.61 to 0.92 million (cases 1 and 2).

\section{Discussion}

For environmental projects, such as exclosures, obtaining comprehensive data set on economic and environmental effects is quite difficult. For instance, besides the effects accounted for in this paper, vegetation restoration in exclosures provides numerous ecosystem functions, such as biodiversity enhancement, microclimate regulation, carbon sequestration and habitat for wild life. However, due to a lack of data these effects were not incorporated in our analysis. As quantification and economic analyses of the effects of most environmental conservation measures are based on anecdotal information and assumptions that may affect the final estimates (Barbier, 1997; Barbier and Burgess, 1997; Enters, 1998), we do recognize that some quantity and value estimates may not accurately reflect the actual environmental services. Therefore, as it is true with findings in other similar studies, our findings are indicative, not definitive. In such circumstances adequate qualitative statements should supplement the quantitative findings for better decisions.

The valuation methods we pursued in this paper may not be considered as the most precise methods. For example, the true economic value of woody biomass could be better captured by valuing its role as a substitute product for animal dung rather than the market prices of fuel wood. If woody biomass production from exclosures substitutes for animal dung for domestic energy, farmers will apply animal wastes in their field to improve soil fertility and increase crop yield (Anderson, 1987). Therefore, future research should focus on a more rigorous approach to capture the value of woody biomass production from exclosures by its indirect effect in increasing crop yield via its impact on soil fertility. This requires estimation of annual dung production, sustainable wood harvest from exclosures, and crop yield response functions to the application of dung.

The hydrology of the study district has improved due to the influence of vegetation cover in exclosures and other soil and water conservation measures. Forests help maintain the base flow levels in streams and rivers (Pattayanak, 2004). Greater availability of water reduces households' water collection cost. As rural households in Ethiopia spend significant amounts of time and labor in water collection, more availability of water has an important economic value. Consequently, the value of the hydrological effect of exclosures can be derived from households' welfare gain attributed to hydrological improvements induced by exclosures. Therefore, future research should focus on capturing value estimates for larger number of environmental functions and choosing more appropriate valuation methods. Research should also pay attention on cataloging geo-referenced data on the spatial distribution of exclosures across the landscape and relative to other land uses for better understanding of the economic and environmental effects of exclosures.

\section{Conclusion and policy implications}

With limited data available, this paper captured the benefits and trade-offs of establishing exclosures on lands with varying opportunity costs. Focusing mainly on the environmental services of soil and water conservation aspect of exclosures and the ensuing economic values, our analysis indicates that establishing exclosures in degraded less productive land yields a large positive net present value. However, converting productive agricultural land to forestry yields a negative net present value even under some hypothetical scenarios of high forest product prices and a low social discount rate.

Sensitivity analysis indicates that the net present value is sensitive to changes in biomass production and the social discount rate. Two important implications can be drawn from this result. First, appropriate forest management schemes have to be adopted in order to enjoy the maximum attainable biomass products from exclosures. If good management schemes are in place converting even semi-productive lands to exclosures increases efficiency in land resource allocation. Second, factors that affect local people's time preference, such as credit constraints, must be addressed in order to induce people to discount the future at lower rate.

In the context of the study area our analysis does not provide any rationale for converting productive crop land to forest land. On the other hand, it is economically justifiable to convert less and semiproductive lands to forest land use. The study confirms that past policy of designating marginal lands to exclosures appears justifiable from efficiency point of view. But, since most of the marginal lands in the study area were already converted to exclosures, the trade-offs of future land conversions to forest land use should be carefully analyzed ex ante before such a decision is made.

\section{Acknowledgments}

This research was conducted within the framework of the MU-IUC program which is a 10 year (2004-2013) collaborative research program between the Flemish Universities (Belgium) and Mekelle University (Ethiopia) with the financial support of VUR (Vlaamse Interuniversitaire Raad-Flemish Interuniversity Council). The authors would like to thank Mekelle University for providing logistic support and the two anonymous reviewers for their valuable comments.

\section{Appendix 1}

Table A1. Quantitative values of attributes/variables on which estimates of some of the effects of exclosures were based.

\begin{tabular}{|c|c|c|}
\hline Variable or attribute & Estimate & Remark/comments $^{\dagger}$ \\
\hline $\begin{array}{l}\text { Annual sediment mass } \\
\text { yield (SM) }\end{array}$ & 6625 t year $^{-1}$ & $\begin{array}{l}\text { The estimate was based on } 10 \\
\text { surveyed reservoirs in Tigray. }\end{array}$ \\
\hline $\begin{array}{l}\text { Annual volumetric } \\
\text { sediment yield (SV) }\end{array}$ & $5901 \mathrm{~m}^{3}$ year $^{-1}$ & $\begin{array}{l}\text { The estimate was based on } 10 \\
\text { surveyed reservoirs in Tigray. }\end{array}$ \\
\hline $\begin{array}{l}\text { Specific sediment } \\
\text { yield (SSY) }\end{array}$ & $\begin{array}{l}2.37- \\
18.17 \mathrm{tha}^{-1} \text { year }^{-1}\end{array}$ & $\begin{array}{l}\text { SSY varies significantly (with } \\
\text { average SSY } 9.09( \pm 5) \mathrm{t} / \mathrm{ha} / \mathrm{yr} \text {. }\end{array}$ \\
\hline $\begin{array}{l}\text { Dry sediment bulk density } \\
\text { (average) }\end{array}$ & $1.01-1.42 \mathrm{t}\left(\mathrm{m}^{3}\right)^{-1}$ & $\begin{array}{l}\text { Haregeweyn et al. (2006, } \\
\text { p. 223). }\end{array}$ \\
\hline $\begin{array}{l}\text { Average live storage of } \\
\text { surveyed reservoirs }\end{array}$ & $706 \times 10^{3} \mathrm{~m}^{3}$ & $\begin{array}{l}\text { Haregeweyn et al. (2006, } \\
\text { p. 223). }\end{array}$ \\
\hline
\end{tabular}


(Table A1 continued)

\begin{tabular}{|c|c|c|}
\hline Variable or attribute & Estimate & Remark/comments ${ }^{\dagger}$ \\
\hline $\begin{array}{l}\text { Average dead storage of } \\
\text { surveyed reservoirs }\end{array}$ & $122 \times 10^{3} \mathrm{~m}^{3}$ & $\begin{array}{l}\text { Haregeweyn et al. (2006, } \\
\text { p. 223). }\end{array}$ \\
\hline $\begin{array}{l}\text { Dead storage (DS) as a \% of } \\
\text { total storage volume }\end{array}$ & $9 \%$ & $\begin{array}{l}\text { The distribution of DS ranges } \\
\text { from } 1 \%-20 \% \text {. }\end{array}$ \\
\hline $\begin{array}{l}\text { Construction cost of an } \\
\text { average reservoir }\end{array}$ & ETB 1.5-2.0 million & $\begin{array}{l}\text { This was the cost of } \\
\text { constructing the main dam } \\
\text { (excavation); it did not } \\
\text { include the cost of irrigation } \\
\text { infrastructure. }\end{array}$ \\
\hline $\begin{array}{l}\text { Sediment deposition rates } \\
\text { of exclosures }\end{array}$ & $\begin{array}{l}\text { 25.6- } \\
123.2 \mathrm{tha}^{-1} \text { year }^{-1}\end{array}$ & $\begin{array}{l}\text { The estimates were based on } \\
\text { field measurements of some } \\
\text { selected exclosures in the } \\
\text { study areas (Desceheemaeker } \\
\text { et al, 2006). }\end{array}$ \\
\hline $\begin{array}{l}\text { Weighted average sediment } \\
\text { deposition rates }\end{array}$ & $48.6 \mathrm{t} \mathrm{ha}^{-1}$ year $^{-1}$ & $\begin{array}{l}\text { The ages of exclosures were } \\
\text { used as weights (computed by } \\
\text { the first author). }\end{array}$ \\
\hline $\begin{array}{l}\text { Average bulk density of } \\
\text { deposited sediments in } \\
\text { exclosures }\end{array}$ & $1.24 \mathrm{t}\left(\mathrm{m}^{3}\right)^{-1}$ & $\begin{array}{l}\text { Computed by the first author } \\
\text { from data in Desceheemaeker } \\
\text { et al. (2006). }\end{array}$ \\
\hline $\begin{array}{l}\text { Average storage volume of } \\
\text { surveyed reservoirs }\end{array}$ & $828,000 \mathrm{~m}^{3}$ & $\begin{array}{l}\text { Calculated based on data from } \\
\text { the } 10 \text { reservoirs surveyed. }\end{array}$ \\
\hline Local bank lending rate & $15 \%$ & $\begin{array}{l}\text { This was the rate applied by } \\
\text { the local microfinance institute } \\
\text { (MFI) on money lent to local } \\
\text { borrowers. }\end{array}$ \\
\hline
\end{tabular}

${ }^{\dagger}$ Estimates were based on Haregeweyn et al. (2006), Desceheemaeker et al. (2006), District office of the local MFI (personal communication, 2006), and SAERT(1994).

\section{References}

Anderson, D, 1987. Economic aspects of afforestation and soil conservation projects. Annals of Regional Science 21 (3), 100-110.

Babulo, B., 2007. Economic valuation and management of common-pool resources: thecase of exclosures in the highlands of Tigray, Northern Ethiopia. PhD Thesis. Katholieke Universiteiet Leuven. Belgium. pp213.

Babulo, B., Muys, B., Nega, F., Tollens, E., Nyssen, J., Deckers, J., Mathijs, E., 2008. Household livelihood strategies and forest dependence in the highlands of Tigray, Northern Ethiopia. Agricultural Systems 98, 148-155.

Balana, B.B., Mathijs, E., Muys, M., 2010. Assessing the sustainability of forest management: an application of multi-criteria decision analysis to community forests in northern Ethiopia. Journal of Environmental Management. 91, 1294-1304.

Barbier, E.B., 1997. The economic determinants of land degradation in developing countries. Phil. Trans. R. Soc. Lond. B351 (1356), 891-899.

Barbier, E.B., Burgess, C.J., 1997. The economics of tropical forest land use options. Land Economics 73 (2), 174-179.

Behailu, M., Verplancke, H., van Ranst, E., Haile, M., 2007. Enhancing the productivity of irrigated Vertisols: a comparative study between a traditional method and surge/ intermittent management. Soil Use and Management 23, 36-39.

Bojo, J. 1996. The costs of land degradation in Sub-Saharan Africa. Ecological Economics $16,161-173$.

Bojo, J., Cassels, D., 1995. Land Degradation and Rehabilitation in Ethiopia: A Reassessment. The World Bank, Washington, DC.

Campbell, J., 1991. Land or peasants?: the dilemma confronting Ethiopian resource conservation. African Affairs 9, 5-21.

Clark, R, 1996. Methodologies for the economic analysis of soil erosion control. CSERGEWorking Paper GEC 96-13. Overseas Development Group, University of Anglia, Norwich.

Cleemput, S., 2003. Biomass estimation of herbaceous and woody vegetation in closed areas of northern Ethiopia. unpublished MSc. thesis, Departement Biotechnologische Wetenschappen, Hogeschool Gent. 100 pp.

Descheemaeker, K., 2006. Pedological and hydrological effects of vegetation restoration in exclosures established on degraded hillslopes in the highlands of Northern Ethiopia. $\mathrm{PhD}$ thesis, K.U.Leuven, 350pp.
Descheemaeker, K., Nyssen, J., Rossi, J., Poesen, J., Haile, M., Raes, D., Muys, B., Moeyersons, J., Deckers, S., 2006. Sediment deposistion and pedogenesis in exclosures in the Tigray highlands, Ethiopia. Geoderma 132 (3-4), 291-314.

EFAP, 1993. Ethiopian Forestry Action Programme. Ministry of Natural Resource Development and Environmental Protection, Addis Ababa.

Enters, T., 1998. Methods for the economic assessment of the on- and off-site impacts of soil erosion. International Board for Soil Research and Management. Issues in Sustainable Land Management No.2. Bangkok .

Eshete, G., 1999. Assessment of fuel wood resources in acacia woodlands in the rift valley of Ethiopia: towards the development of planning tools for sustainable management. $\mathrm{PhD}$ thesis. Swedish University of Agricultural Sciences, Umea..

Esser, K., Vagen, T., Yibabe Tilahun, Mitiku Haile, 2002. Soil conservation in Tigray, Ethiopia. Noragic Report No. 5. Noragic, Agricultural University of Norway.

Gebremedhin, B., Pender, J., Tesfay, G., 2004. Collective action for grazing land management in mixed crop-livestock systems in the highlands of northern Ethiopia. Agricultural Systems 82, 273-290.

Gillam, S., 2004. Protecting the forest. Report of the farm Africa project (memo). Addis Ababa, Ethiopia.

Gittinger, P.J., 1982. Economic Analysis of Agricultural Projects, 2nd ed. The World Bank, Washington, D.C., USA.

Grohs, F., 1993. Economics of soil degradation, erosion and conservation: a case study of Zimbabwe. PhD thesis, Universität Hohenheim.

Haregeweyn, N., Poesen, J., Nyssen, J., De Wit, J., Haile, M., Govers, G., Deckers, S., 2006. Reservoirs in Tigray (Northern Ethiopia); characteristics and sediment deposition problems. Land Degradation and Development 17 (2), 211-230.

Hicks, J.R., 1939. The foundations of welfare economics. The Economic Journal 49 (196), 696-712.

Jagger, P., Pender, J., 2003. The role of trees for sustainable management of lessfavoured lands: the case of eucalyptus in Ethiopia. Forest Ecology and Economics 5 (1), 83-95.

Kaldor, N., 1939. Welfare propositions of economics and interpersonal comparison of utility. The Economic Journal 49 (195), 549-552.

Kramer, R.A., Richter, D.D., Pattayanak, S., Sharma, N.P. 1997. Ecological and economic analysis of watershed protection in Eastern Madagascar. Journal of Environmental Management 49, 277-295.

Mekuria, W., Veldkamp, E., Haile, M., Nyssen, J., Muys, B., Gebrehiwot, K., 2007. Effectiveness of exclosures to restore degraded soils as a result of overgrazing in Tigray, Ethiopia. Journal of Arid Environments 69, 270-284.

Newcombe, K., 1987. An economic justification for rural afforestation: the case of Ethiopia. Annals of Regional Science 21 (3), 80-99.

Pattanayak, S.P., Mercer, E.D., 1996. Valuing soil conservation benefits of agroforestry practices. Southeastern Center for Forest Economics Research, Research Triangle Park, NC. FPEI Working Paper No. 59

Pattayanak, S.K., 2004. Valuing watershed services: concepts and empirics from Southeast Asia. Agricultural Ecosystems and Environment 104 (1), 171-184.

Pattayanak, S.P., Kramer, RK, 2001. Worth of watersheds: a producer surplus approach for valuing drought mitigation in Eastern Indonesia. Environment and Development Economics 6 (1), 123-146

Raes, D., Greets, S., Kipkorir, E, Wellens, J., Sahli, A., 2006. Simulation of yield decline as a result of water stress with a robust soil water balance model. Agricultural Water Management 81 (3), 335-357.

Roebben, M., 2004. Biomassa en bladwaterpotentiaal in herstellend droogbos in het hoogland van Tigray, Ethiopië. unpublished MSc. thesis, Department of Land Management and Economics, K.U.Leuven. 90pp.

SAERT, 1994. Sustainable agriculture and environmental rehabilitation in Tigray, basic text, unpublished, Mekelle.

Tadesse, G., 2001. Land degradation: a challenge to Ethiopia. Environmental Management 27 (6), 815-824.

Teketay, D., 2001. Deforestation, wood famine, and environmental degradation in Ethiopia's highland ecosystems: urgent need for action. Northeast African Studies 8 (1), 53-76.

Tesfay, G., 2006. Agriculture, resource management and institutions: a socioeconomic analysis of households in Tigray, Ethiopia. PhD Thesis. Wageningen University, The Netherlands. pp 170.

TFAP, 1996. Tigray Forestry Action Programme. Bureau of Agriculture and Natural Resources Development, Mekelle.

Tilahun, M., Olschewski, R., Kleinn, C., Gebrehiwot, K., 2007. Economic analysis of closing degraded Boswellia papyrifera dry forest from human interventions-a study from Tigray, Northern Ethiopia. Forest Policy and Economics 9 (8), 996-1005. 
